\title{
ELUM: The Public Communication's App for Municipal Cultural Indicators
}

ELUM: o aplicativo de comunicação pública para indicadores culturais municipais

ELUM: la aplicación de comunicación pública para indicadores culturales municipales

\section{Tiago Costa Martins}

$\mathrm{PhD}$ in Regional Development at University of Santa Cruz do Sul. Professor for undergraduate programs in Public Policies at Federal University of Pampa and Cultural Heritage at Federal University of Santa Maria. Assistant researcher at Centro de Investigação Transdisciplinar Cultura, Espaço e Memória - CITCEM, University of Porto, Portugal. tiagomartins@unipampa.edu.br

0000-0003-0927-7148

\section{Claiton Marques Correa}

$\mathrm{PhD}$ Candidate in Computer Science at Pontifical Catholic University of Rio Grande do Sul.

Professor for graduate curse in Information System at Farroupilha Federal Institute. claiton.correa@iffarroupilha.edu.br.

0000-0003-2339-1844

\section{Fernando Luis Oliveira}

PhD Candidate in Computer Science at Federal University of Pelotas. Professor for graduate curse in Information System at Farroupilha Federal Institute. fernando.oliveira@iffarroupilha.edu.br.

\section{0-0002-9158-8879}

\section{Ícaro Lins Iglesias}

Master in Education at Polytechnic Institute of Porto, Portutal. Professor for graduate curse in Information System at Farroupilha Federal Institute. icaro.iglesias@iffarroupilha.edu.br.

0000-0002-9236-3102

Correspondência: Universidade Federal do Tocantins, Reitoria, DIRETORIA DE COMUNICAÇÃO. Quadra 109
Norte Avenida NS 15, Plano Diretor Norte, 77001090 Palmas, TO - Brasil.

Received: 02.16.2021.

Accepted: 04.16.2021.

Published: 07.01.2021.

\begin{abstract}
:
This article presents the result of the research on the articulation between indicators, cultural policies, public communication, and the allocation of resources carried out by the municipal public administrations in Rio Grande do Sul (Brazil). In the study, the vision of a propositive science is associated with technological resources that create algorithms and model applications with different functionalities. An algorithm associated with a software was developed: Elum. Therefore, it is reported the research trajectory - in which the accessed data were treated (as indicators) and communicated (as public communication) - in intention to generate a cognitive equivalence between those who have them and those who have a potential interest in understanding them.
\end{abstract}

KEYWORDS : Information systems; Cultural policy; Public administration.

\section{Introduction}

We present in this paper the research's findings on the articulation between social indicators, cultural policies, public communication, and allocation of resources carried out by the municipalities of Rio Grande do Sul. Agents and institutions establish contact with territorial reality and assume the responsibility of cultural policies development. The public municipal administration, municipal government, is an example of an agent that holds the culture promotion/organization/structuring in the municipalities. 
The city halls' protagonism relies on the assignment of public resources as an allocation public policy. These resources assigned to culture are, obviously, of public interest. Currently, transparency, accountability, and social control are established by legal devices and translated into information access portals, transparency portals, and social control.

The "social control" of the Court of Auditors of Rio Grande do Sul is an example of a portal that provides primary data about municipalities' expenses, including those related to culture. In total, the open dataset available in the portal comprises 497 municipalities of Rio Grande do Sul. However, it is hardly used due to the way it presents this information ${ }^{1}$.

The transformation process of public entity data into a reasonable interpretation to the citizens became a subject of interest. For this purpose, public communication established the following debate: through communication, it is possible to decrease "the cognitive mismatch" (MATOS, 2019). Hence, this research built a set of municipal cultural indicators from public expenditures available in the Court of Auditors of Rio Grande do Sul portal. Public communication has been set in front of algorithms, interfaces, and devices that reordered specific phenomena (LEMOS, 2020), such as those related to individuals in the social control of public policies (SILVA, 2002). By building a sociotechnical system of indicators to analyze data from the expenditure of Rio Grande do Sul municipalities, this movement enabled the development of an information source for public communication. Thus, the paper relates the development of a public communication artifact through experimental software.

\section{Indicators for public communication, public communication for the indicators}

The relation between indicators and communication has been articulated since 1980 with the International Conference on Communication, Mexico. The meeting of intellectuals from the communication field pointed out the concern of discussing "the future of advanced societies". By the influence of George Gerbner (1919-2005), the indicators had been taken as a means to unveil specific reality: analysis of the dramatic television content and its effects on the viewers (see the second chapter of this research).

The context established here is recognizing the cultural indicators as a means carried with some intent. Therefore, the indicator is not an end in itself but a numerical solution that works to achieve a specific goal.

\footnotetext{
${ }^{1}$ Available at: www.tce.rs.gov.br by "Controle Social" or at http://dados.tce.rs.gov.br
} 
By recognizing that "the numerical solutions for the social and political subjects seem to be everywhere and they cannot let influence the public life standards" (REDDEN, 2015 , p. 27), the indicators for public communication are recognized as a numerical solution that aids the understanding of what is at stake.

The cultural indicators always have been vigorously applied to explain the cultural reality of the State, economy, and society, but seldom to articulate this reality and present it to society. Consequently, only with "culture and governance" and "culture and democracy" politicals and scientific movements there was the recognition of providing a society input of "behavior" of the State, for instance (MARTINS and PINTO, 2019).

Thus, the society inputs can be analyzed with the indicators that are helpful to empower the citizens with a device to interpret "what is happening" in the cultural reality, especially by the civil society leading (instead of political society) and the reconfiguration of governments in the democratic procedures. In this sense, the indicators are known as governance and communication mechanisms (DUXBURY, 2005) or tools for political debate (FUKUDA-PARR, 2000).

In contrast, public communication should create the communicative relations flows for seeking a cognitive equivalence to the public interest switches into a debate between government and society. The operating performance of public communication points to a strategic action that is propositive to the production of conversation through the indicators. This situation reinforces that the communication is in a broad context of knowledge democratization to decrease "the cognitive mismatch" (MATOS, 2009).

Thus, the tenets recognized and applied by public communication enrich the indicators with "engagement", whereas "a guideline for a proactive and interactive agenda with the society that seeks for engagement and participation" (MARTINS and PINTO, 2019, p.34). So then, we aim at what is applicable and recognized as information and knowledge by public administration to be equally by citizens.

\section{How the app was built}

The Elum is a socio-technical artifact experimentally developed as an information tool for public communication ${ }^{2}$. Through data transformation into indicators, it is an

\footnotetext{
2 The name Elum emerges from the junction of the words "elo" (link in Portuguese) and "um" (one in Portuguese). The name pay tribute to the rock bands from the city of Santa Maria, RS, that grounded, in the nineties, an independent scenario to the promotion of their art through a compact disc named "Elo ". The idea of the first chain link is associated because the city hall investment is the first link of a value chain to culture.
} 
application that seeks to create an information system that enables the equivalence between municipal accountability and the citizens' read and comprehension.

The Court of Auditors of Rio Grande do Sul (TCE in Portuguese) provides, following Law 4320/64, the budgets expenditures by pledges that contain information related to the budgets expenditures of Powers or Entities from the municipal sphere. Generally speaking, these are open data available for anyone at http://dados.tce.rs.gov.br.

However, specific information is not suitable for reading or interpretation due to its complexity or volume. In practical terms, the TCE provides its data in CSV (Comma Separated Values) file format. This format can be used to exchange data between applications. The files provided by TCE contain thousands or even millions of records which requires a high-performance computer to visualize their content. It is essential to highlight that even if someone can visualize the information, she or he hardly would be able to understand or get some knowledge from it.

In this sense, considering the lack of proper solutions to this purpose, we planned the Elum aiming to facilitate information access.

We organized the software development into four phases: a) data extraction and transformation; b) database construction; c) development of a web system; d) public communication operationalization.

Data extraction and transformation: the files provided by TCE contain data that are supplied by the city halls of Rio Grande do Sul state, and there is no pattern defining the way the information is included. Usually, each city hall has its manager system or organization policies that influence how the data are provided. For example, acronyms, abbreviations, or codes are commonly employed to describe pledges.

In this regard, this situation required a way to extract and analyze each record to ensure the standardization of data input without changing the original information. For example, the creditor related to a pledge can be a private individual or a legal entity identifier. When private individual registration (CPF in Portuguese) or national legal entity registration (CNPJ in Portuguese) begins with zero, this information is omitted by some city halls. It occurs once CPF/CNPJ is handled as an integer, i.e., the zero on the left has no meaning, and then it is omitted. Hence, such occurrences must be treated to standard and restore the original information.

Database after the extraction phase, a database was built to record and make it possible to access the information. 
System. this phase comprised the development of software that manages the information from the database. This software enables information handling, database queries, and report construction.

To develop the software, we adopted the Java programming language because, according to Mendes (2010), this is more than a programming language; it is a development platform whose main advantage is to be compatible with various operation systems: Windows, Mac OS, Linux, among others.

Public communication operationalization. this phase involves communication operationalization through strategic resources that enable us to reach the "communicability" property and the "communicable" effect on the cultural indicators.

\section{The process of importation}

The TCE annually provides municipal accountability. The CSV file containing, on average, 19 million records is usually published in mid-April. Each row in the file contains 36 data separated by a comma. These data describe the pledge, including launch date, creditor identifier (CPF or CNPJ), amounts paid, committed, settled, and accounting function.

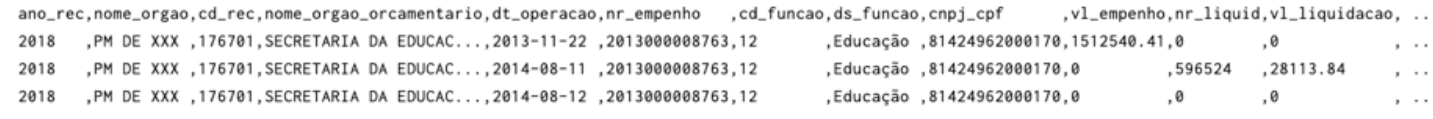

Figure 1: sample of a CSV file.

Source: Martins et al. (2021)

Figure 1 shows a CSV file summary that contains twelve terms separated by a comma at the first line. These values stand for the document headers, which are indicators of each datum origin ${ }^{3}$. Table 1 depicts the data from files already processed that were imported to Elum. It is essential to say that the data release always presents some gap, i.e., the data analyzed in the current year refers to the previous budget year. We highlight that the data between 2017 and 2019 contains more than 61 million evaluated and processed rows.

\footnotetext{
${ }^{3}$ In this image, to make it easy for data visualization, we treated the information only for demonstrative purposes to make all the content encompass the same number of characters. The intent is to show the way the data are provided to the community.
} 


\begin{tabular}{c|c|r|r}
\hline Reference year & Date of publication & Total of records & Size of the files (MB) \\
\hline 2017 & $26 / 04 / 2018$ & 19.494 .446 & 905,5 \\
\hline 2018 & $24 / 04 / 2019$ & 20.468 .603 & 967,6 \\
\hline 2019 & $24 / 04 / 2020$ & 21.377 .770 & 1070,3 \\
\hline
\end{tabular}

Table 1: Data from the files already processed, and published by TCE.

Source: Martins et al. (2021).

\section{The creditor importation}

The creditor identification was a challenge in the importation process. The CSV file contained only a single column to represent this information. As a result, it was not possible to determine whether the information referred to a private individual or legal entity in some cases. It happened because the number within that column did not match a CPF or CNPJ identifier.

We believe that this problem occurred because this information was, at some step in TCE or city halls systems processing, this information was treated as an integer. Consequently, the numbers beginning with zero had this value omitted what disfigured their original format. Considering the premise that the CPF and the CNPJ contain 11 and 14 digits, respectively, we developed an algorithm that analyzes the number to add zeros on the left until the number reaches the quantity of digits of each category. After this process, the value is checked to determine whether it is a valid CPF or CNPJ. In some instances, the evaluations can consider the number as not identified. Nevertheless, these occurrences do not represent a representative amount. Table 2 shows the values collected and categorized by year.

\begin{tabular}{l|r|r|r|c}
\hline Year & Valid CPFs (\%) & $\begin{array}{r}\text { Valid CNPJs } \\
(\%)\end{array}$ & Not identified (\%) & Total of records \\
\hline 2017 & $\begin{array}{r}168410 \\
(60,76)\end{array}$ & $107656(38,84)$ & $1127(0,41)$ & 277.193 \\
& & & \\
\hline 2018 & $78860(73,99)$ & $27575(25,87)$ & $149(0,14)$ & 106.584 \\
\hline 2019 & $70634(74,5)$ & $24690(25,88)$ & $60(0,06)$ & 95.384 \\
\hline Total & $\begin{array}{r}317904 \\
(66,35)\end{array}$ & $159921(33,38)$ & $1336(0,28)$ & 479161 \\
& & & \\
\hline
\end{tabular}

Table 2: Total of creditors by year.

Source: Martins et al. (2021).

It is possible to note in Table 2 a significant quantity of records associated with the year 2017 compared to the other years. This volume is because all the creditors were 
evaluated that year, once it was the first data processing. In the subsequent years, only new creditors were analyzed, i.e., a creditor included in 2017 was not analyzed in 2018; the ones included in 2018 were not analyzed in 2019.

A smaller percentage of creditors $(0,28 \%)$ could not be identified as private individuals or legal entities. This limitation occurred because some city halls used customized codes to identify their creditors. These codes did not follow any pattern or convention, i.e., they are freely defined and used by municipalities.

To identify whether a record has already been processed or not, we considered the CPF or CNPJ code informed in the importation file. Therefore, for each row in the file, the algorithm extracted the value from column "cnpj_cpf", then it checked if the value existed in the database; if it did not exist, the algorithm inserted it in the database. To complement the creditor's data inserted, we used the content of the column "nm_credor" as a description (name/corporate name).

Although this strategy is functional and meets the importation process, it has a side effect. Within this dynamic, the codes that are not valid CPF or CNPJ can repeat. This repetition means that there is no reliable description of the creditor. For example, consider that the code 00000000000 is used by municipality $A$, whose associates this code to the description "guardianship councilors". When this code is processed, it will be included in the database using the information adopted by municipality $A_{;}$however, it will be classified as "not identified". In this sense, if a second municipality employs the same code to describe a different creditor, the current process considers that this new creditor has already been included in the database. As a result, the description may be misplaced in some locals.

\section{Database}

We adopted the relational approach to persist the data. In this approach, the data are stored in tables that relate to one another. We employed PostgreSQL as Data Base Management System.

PostgreSQL is a free, open-source system that implements an object-relational model of persistence. This tool can serve, satisfactorily, databases with high volumes of information and present excellent performance (OBE and HSU, 2017).

The Elum database system project encompasses a total of 19 tables. Figure 2 shows the entity-relationship diagram proposed based on the CSV file structure. 


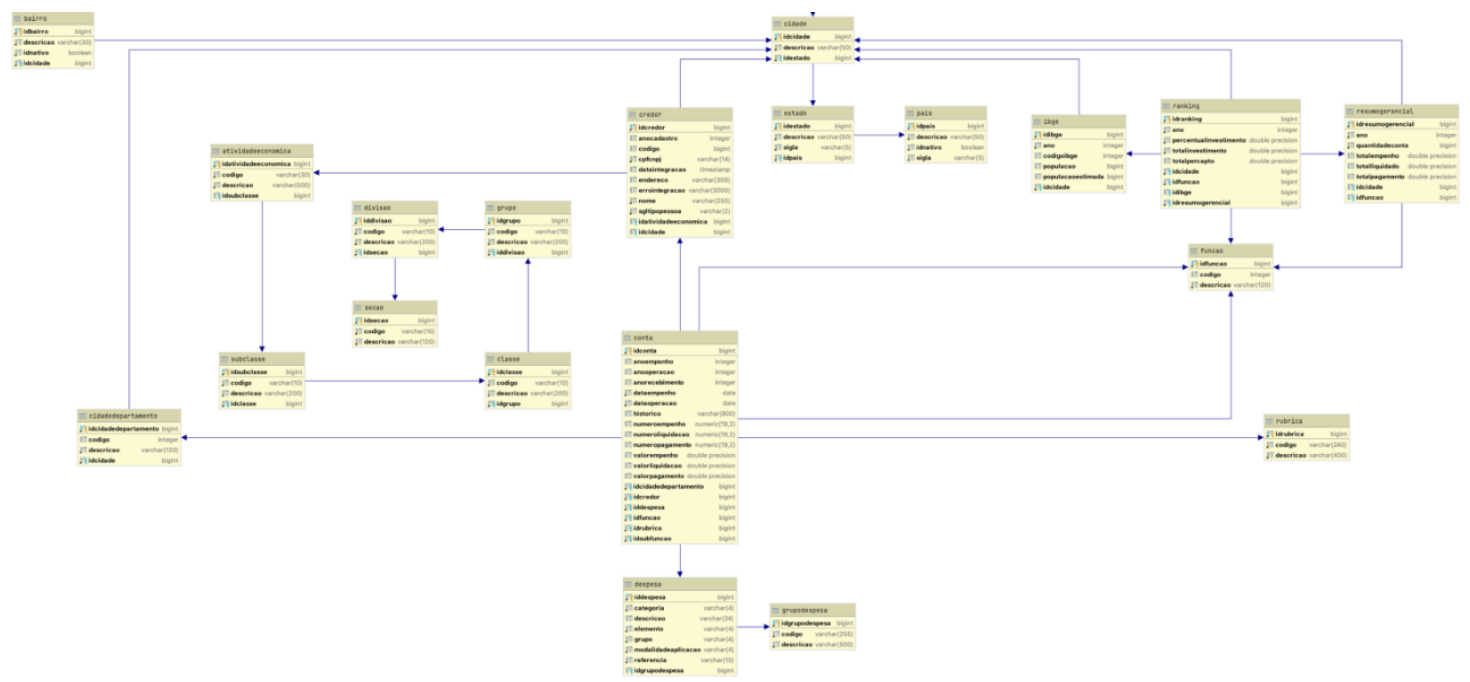

Figure 2: Elum entity-relationship diagram.

Source: Martins et al. (2021).

Figure 2 - database entity-relationship diagram - to avoid redundancy and maintain data integrity, each row analyzed in the importation process from the CSV file will have its content distributed between the tables. Aside from these tables, others that compose the model were omitted once they support the basic system functionalities, such as history, access control, and user profile. Table 3 shows a landscape of the number of records contained in the database.

\begin{tabular}{|l|l|r|}
\hline Table & Description & Total of records \\
\hline Credor & Stores creditor data from city halls. & 479,161 \\
\hline Função & $\begin{array}{l}\text { The accounting function assigned by the } \\
\text { city for the ordering of expenses. }\end{array}$ & 175 \\
\hline Cidade & $\begin{array}{l}\text { Data referring to the municipality of the } \\
\text { state of RS and municipalities associated } \\
\text { with creditors that are legal entities. }\end{array}$ & 1,129 \\
\hline Cidade Departamento & $\begin{array}{l}\text { Refers to the department or agency within } \\
\text { the municipality linked to the effort. }\end{array}$ & 1,497 \\
\hline Resumo Gerencial & $\begin{array}{l}\text { Stores the values summed and grouped } \\
\text { by municipality and year, used for } \\
\text { summaries, statistics and rankings. }\end{array}$ & 1,491 \\
\hline IBGE & $\begin{array}{l}\text { Maintains population estimate data for } \\
\text { each municipality per year. This } \\
\text { information is provided by the Brazilian } \\
\text { Institute of Geography and Statistics. }\end{array}$ & 2,994 \\
\hline Ranking & $\begin{array}{l}\text { Table used to create classification } \\
\text { groupings, according to indicators. }\end{array}$ & 14 \\
\hline Despesa & Expense associated with the commitment. & \\
\hline Grupo Despesa & Classification to group expenses. & \\
\hline
\end{tabular}




\begin{tabular}{|l|l|r|}
\hline Conta & $\begin{array}{l}\text { Registers the commitments that each } \\
\text { municipality declared with the TCE. }\end{array}$ & $61,340,819$ \\
\hline Rubrica & & 10,670 \\
\hline Estado & Federative unit. & 27 \\
\hline Pais & & 1 \\
\hline Atividade Econômica & & 1,089 \\
\hline Subclasse & & 1,334 \\
\hline Classe & & 681 \\
\hline Grupo & & 285 \\
\hline Divisão & & 87 \\
\hline Seção & & 21 \\
\hline
\end{tabular}

Table 3: Description of tables and number of records.

Source: Martins et al. (2021).

\section{How the software was developed}

The software was idealized to be accessed through an internet browser, implying adopting a client-server model. In this approach, the system users are known as clients. They access applications remotely processed, i.e., a computer (server) is accounted to receive clients' requests, process them, and reply to the users.

Regarding this perspective, the tool has two segmentations: the part processed in the client was developed using HTML, CSS, and JavaScript languages; the server segmentation was developed using Java programming language.

\section{Client segment}

The client part is related to the content they visualize and interact with. It represents the users' interface that establishes the content transmission and communication. This interface requires study and planning to develop user-friendly interfaces that support the users in interacting with the application. According to Krug (2006), many aspects that vary from elements position, colors languages, sizes, and images, among others, influence systems planning and construction. In this sense, to abstract the complexity of how the system works and make the application friendly and straightforward to users explore naturally, we employed Human-Computer Interaction $(\mathrm{HCl})$ techniques.

Figure 3 shows the interface proposed. In this tab, the user can opt to visualize data related to culture (default option) or tourism. However, regardless of choice, it is required to select the city and the year of reference. In practical terms, culture and the year 2017 are selected by default. 


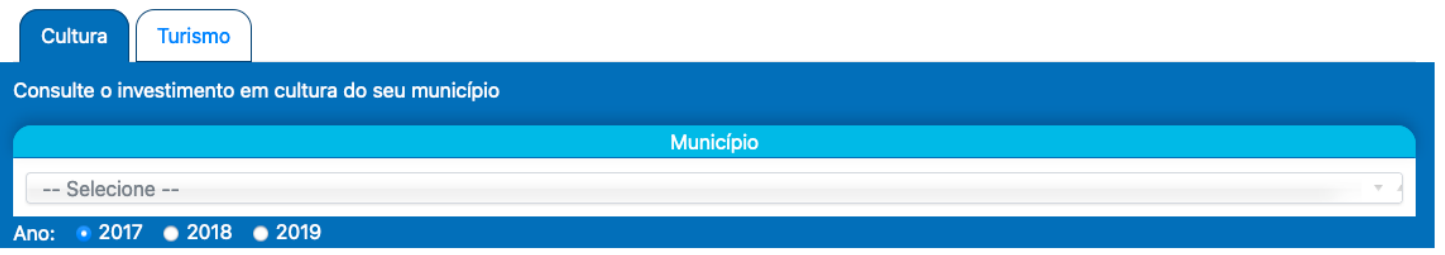

(i) Por favor, selecione uma cidade para visualizar os indicadores.

Figure 3: Initial interface proposed.

Source: Martins et al. (2021).

\section{Server segment}

The server performs the procedures and treatments required to generate the indicators, i.e., database queries, data aggregation, process, and classify the results. On the server, all the business rules are built, i.e., the application logic. To accomplish this task, we adopted some software design patterns: MVC (Model, View, Controller), DAO (Data Access Object), Factory, Decorator, Facade, among others.

Eclipse was adopted as the development environment and the Apache Tomcat as the runtime system regarding the tools employed. In addition, to versioning the code, we adopted Git.

To design the application structure, we considered thorough planning to ensure the application can be evolved and maintained straightforward, but especially to enable other people to interact, understand, and maintain the code. Finally, to analyze the work done, we applied a tool to check the quality of the solution and provide some technical statistics about the system. Table 4 shows this information.

\begin{tabular}{l|c}
\hline Technical indicator & Quantity \\
\hline Total lines of code & 4,376 \\
\hline Total of classes & 107 \\
\hline Total packages & 27 \\
\hline Total external library packages & 51 \\
\hline Total classes belonging to external libraries used & 142 \\
\hline
\end{tabular}

Table 4: Technical statistics.

Source: Martins et al. (2021).

Table 4 presents the statistics extracted from the software source code. The metrics analysis process, and the information about the quality of the code produced, are provided by the CodeMR tool. This tool makes it possible to generate metrics of complexity, cohesion, coupling, and code size. 
(A) Complexity

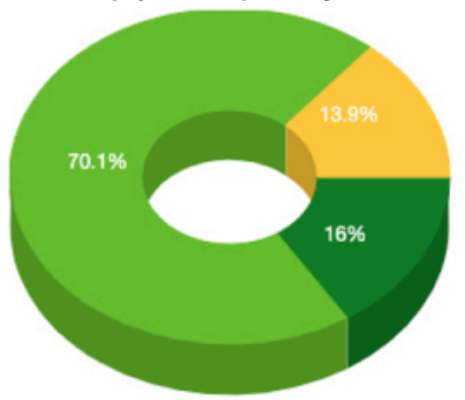

(C) Lines of code

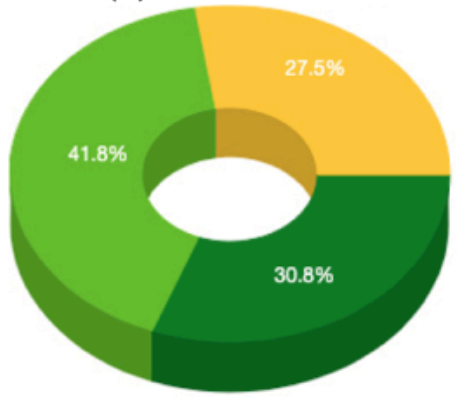

(B) Size

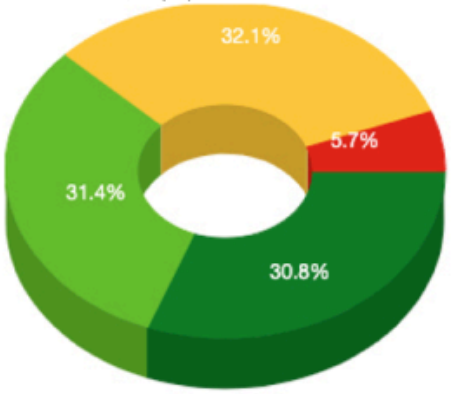

(D) Cohesion lack

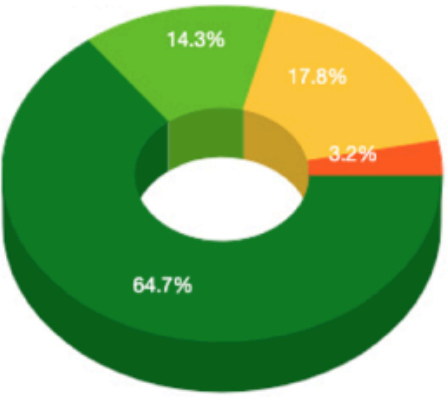

Very high

High

Medium

Low

Very low

Figure 4: Quality of code statistics.

Source: Martins et al. (2021).

Figure 4 shows graphics that highlight the quality of the program developed. It is possible to observe that the code has low complexity (section A), from which $70 \%$ is classified as low and $13 \%$ as medium complexity. This information does not mean that the code is written in straightforward logic or a small program. Conversely, it is organized and structured to split complex structures into smaller units, making it easy to develop and maintain.

Regarding the size (section B), the graphic shows how great the application's files are. To this end, the total of lines and the number of actions developed in each file are considered. The greater the tasks are done, the greater the chances that the code is poorly measured. Two classes responsible for importing the CSV file are classified with high weight in this specific case. Therefore, this classification is reasonable given the circumstances processed while the data is imported.

In respect of the number of lines (section C), the system presents a proper performance. It can be observed that the classes are classified from medium to low. This classification occurs due to the design standards adopted that split the logic into different structures, decrease the number of lines per file, and enhance code reuse.

Finally, cohesion lack indicator (section D) points the code mature. Only one class has been classified as not cohesive, which means this item was classified as "confusing". 


\section{Obevisto}

e-ISSN nº 2447-4266

Palmas, v. 7, n. 3, p. 1-17, jul.-set., 2021 http://dx.doi.org/10.20873/uft.2447-4266.2021v7n3a11en

This indicator employs a complex logic to determine the file status; it considers the total of lines, actions, and attributes, aside from analyzing how the file resources are used. From a technical point of view, the application presents excellent metrics and proper performance. Therefore, the Elum application is informative and a robust and efficient solution.

\section{Results}

The application was developed based on the ideas of the frequently asked questions - FAQ. The bias of communication is intended to transform the application into a tool of self-knowledge.

The search for a communication "effect" was built from articulating the communicability of indicators and the user/citizen possible placement. This way, the focus of the indicators exhibition is on the questions rather than their presentation.

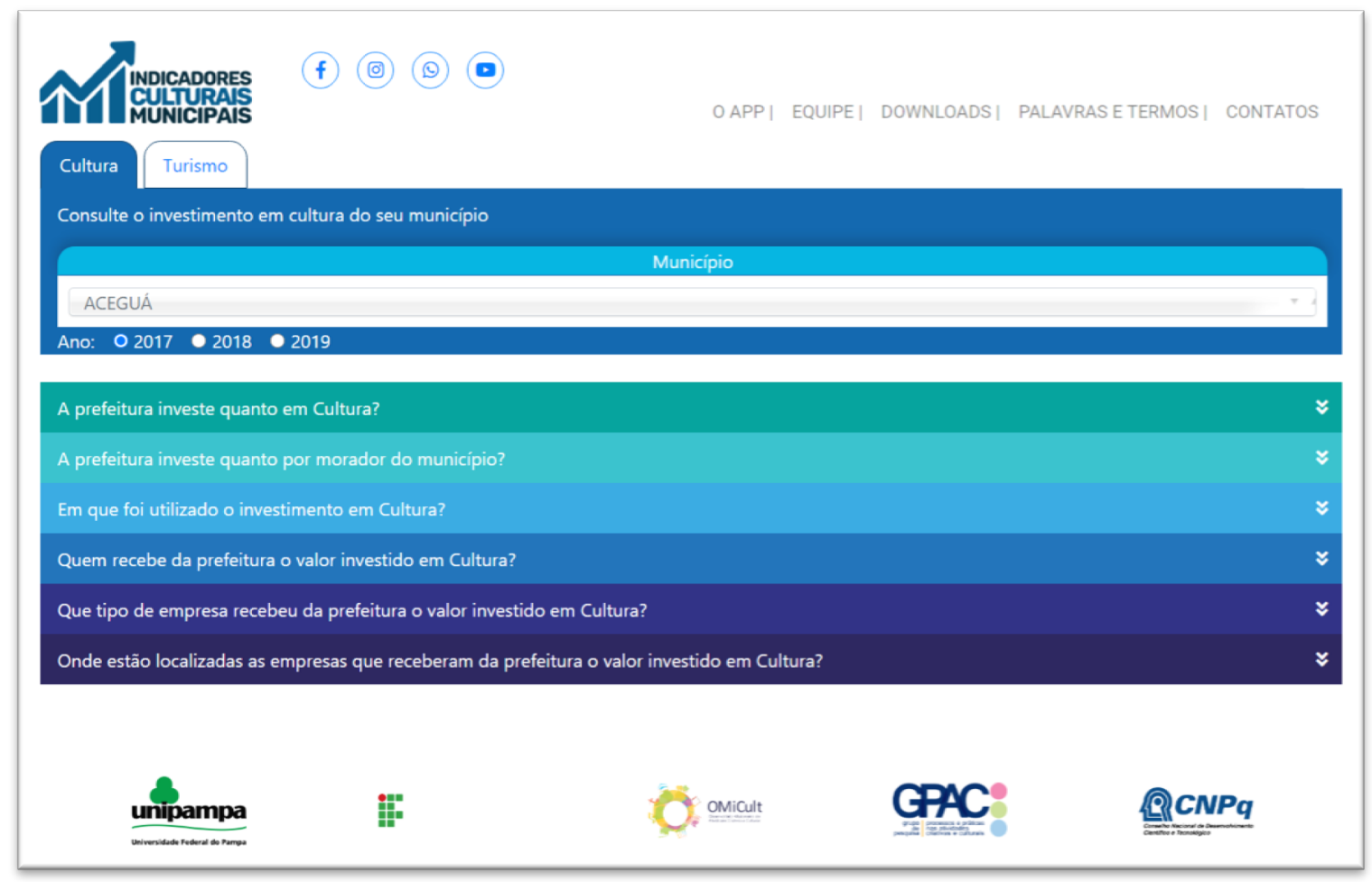

Figure 5: Elum - Questions arrangements.

Source: Martins et al. (2021).

Facilities as images, icons, and rapid access buttons to information were also implemented in the application. Each question or answer, i.e., each indicator, is represented by a color. The goal was to develop a visually pleasing application that 
provides the interaction to seek reflection and action about what it summarizes. Figures

6 and 7 show some resources employed.

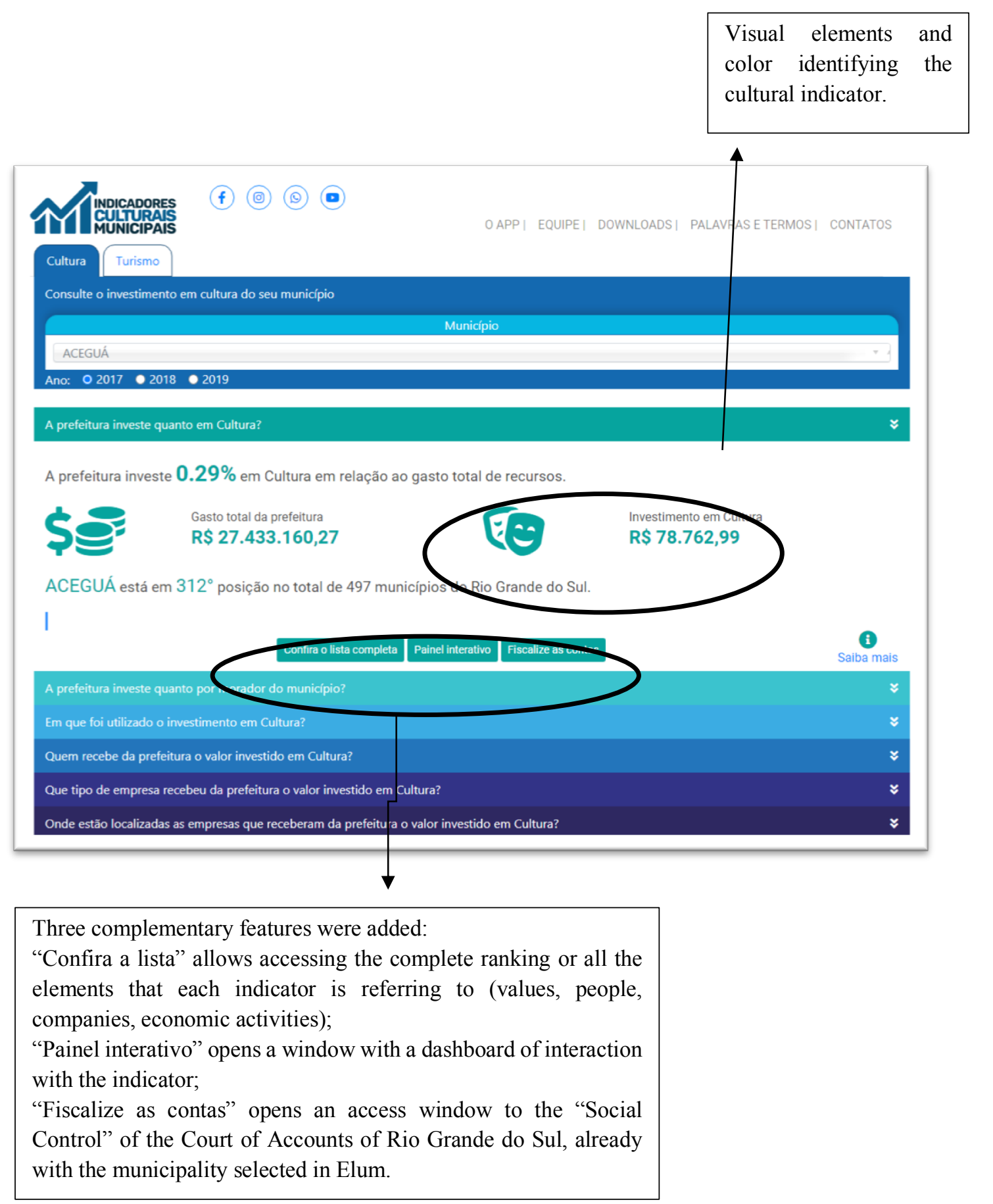


0 que se quer 0 percentual (\%) de investimento em Cultura em relação ao gasto total da prefeitura. saber?

O indicador $\mathrm{E} \quad U m$ valor numérico que representa os recursos financeiros utilizados para fomentar a Cultura em relação a todos os gastos da prefeitura em um determinado ano.

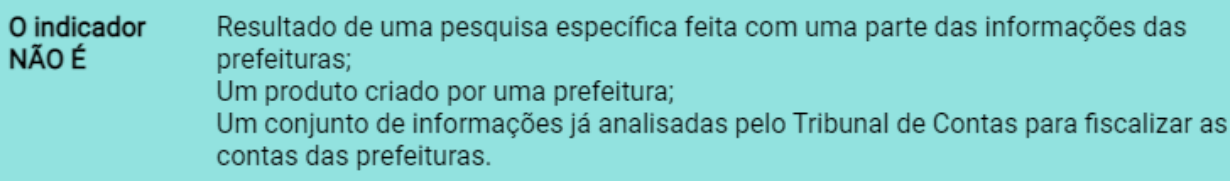

O indicador A transformação dos dados em uma representação visual que permite uma FAZ compreensão mais fácil;

A comparação de investimento em Cultura entre as prefeituras do RS.

\begin{tabular}{|c|c|}
\hline $\begin{array}{l}\text { O indicador } \\
\text { NÃO FAZ }\end{array}$ & $\begin{array}{l}\text { A especificação de quais os setores da Cultura recebem investimento; } \\
\text { Uma análise do que foi classificado e investido como Cultura pela prefeitura. }\end{array}$ \\
\hline $\begin{array}{l}\text { Unidade de } \\
\text { medida }\end{array}$ & Percentual (\%) \\
\hline Fórmula & (Investimento Cultura prefeitura $(\mathrm{R} \$) \times 100)$ / Despesa total prefeitura (R\$) \\
\hline Periodicidade & Anual \\
\hline Espacialidade & Municípios \\
\hline $\begin{array}{l}\text { Fonte de } \\
\text { dados }\end{array}$ & Tribunal de contas do Estado do Rio Grande o Sul \\
\hline Importante & $\begin{array}{l}\text { O indicador utiliza os dados da "Função } 13 \text { - Cultura" e da "Subfunção } 695 \text { - Turismo" } \\
\text { dentro do orçamento das prefeituras. Portanto, o que é cultura e turismo para cada } \\
\text { prefeitura dependerá da forma como ela vai aplicar os recursos públicos nesses } \\
\text { setores. Para saber mais, consulte "PALAVRAS E TERMOS". . }\end{array}$ \\
\hline
\end{tabular}

\section{^. Baixar os dados}

Figure 7: Elum application (on the detail "ficha do indicador"). Source: Martins et al. (2021). 


\section{Final remarks}

In respect of the themes that articulate the research presented in this work, namely culture, public policies, social control, and communication, there is much yet to be done to provide a tool that enables the cultural monitoring and the development of helpful information about the indicators formation, reflection, and action to the engaged sectors.

From the theoretical debate elements to the challenge of operationalizing public communication through the six cultural indicators setting, in this research, we developed an algorithm associated with software: The Elum. At this point, the propositive science view is associated with technological resources that build algorithms and model applications with diverse functions.

When an algorithm is developed to treat municipal public expenditures data and project indicators to social control of specific policy, it operationalizes public communication with a political socio-technical system. The data we accessed in this research were treated (as an indicator) and communicated (as public communication) to generate cognitive equivalence between who provides them and who may be interested in comprehending them.

Finally, it is worth mentioning that the communication field needs to increasingly articulate with other knowledge research fields, including information systems. It presents epistemological implications to the communication knowledge construction face the algorithms and interfaces; and methodological to the employment of methodologies that can think and develop constructs, models, and instantiations able to generate solutions for problems placed in the social reality.

\section{Acknowledgments}

The authors acknowledge the Conselho Nacional de Desenvolvimento Científico e Tecnológico - Brazil - (CNPq) for the grant to this research project (process: 425620/20166) and by the research productivity scholarship (306958/2019-8).

\section{References}

DUXBURY, Nancy. Cultural Indicators and Benchmarks in Community Indicator Projects. In: ANDREW, Caroline et al. (Org.). Accounting for Culture: thinking through cultural citizenship. Ottawa: Ottawa Press, 2005. p. 257-272. 
FUKUDA PARR, Sakiko. En busca de indicadores de cultura y desarrollo: avances y propuestas. In: UNESCO. Informe Mundial sobre la cultura 2000-2001. Paris: UNESCO, 2000. p. 278-283.

KRUG, Steve. Não me faça pensar!: uma abordagem de bom senso à usabilidade na web. Alta Books, 2006.

LEMOS, André. Epistemologia da comunicação, neomaterialismo e cultura digital. Galaxia, São Paulo, n. 43, p. 54-66, jan./abr. 2020. Disponível em: http://dx.doi.org/10.1590/1982-25532020143970. Acesso em: fev. 2021.

MATOS, Heloisa. Comunicação pública, esfera pública e capital social. In: DUARTE, Jorge (Org.). Comunicação pública: Estado, mercado, sociedade e interesse público. São Paulo: Atlas, 2009. p. 47-58.

MARTINS, Tiago Costa; PINTO, Maria Manuela Azevedo. Indicadores culturais, accountability e envolvimento. In: MARTINS, Tiago Costa; PINTO, Maria Manuela Azevedo; SILVA, Armando Malheiro da (Orgs.). Indicadores culturais no Brasil e em Portugal: subsídios para a comunicação entre Estado e Sociedade. Coleção: icultura\&media n. 5. Porto: FLUP/UPORTO, 2019. p. 19-37.

MENDES, Ricardo. Java Web Start. Java magazine, Grajaú, ed. 82, p. 36-43, 2010.

OBE, Regina O.; HSU, Leo S. PostgreSQL: Up and Running: a Practical Guide to the Advanced Open Source Database. Sebastopol, Califórnia: O'Reilly Media, Inc.", 2017.

REDDEN, Guy. Culture, Value and Commensuration: the knowledge Politics of Indicators. In: MACDOWALL, Lachlan et al. (Org.). Making culture count: the politics of cultural measurement. Melbourne: Palgrave Macmillan, 2015. p. 27-41.

SILVA, Francisco Carlos da Cruz. Controle social: reformando a administração para a sociedade. O\&S, v. 9, n²4, p. 115-137, mai./ago. 2002.

\section{RESUMO:}

Este artigo apresenta o resultado da pesquisa sobre a articulação entre indicadores, políticas culturais, comunicação pública e a alocação dos recursos realizada pelas administrações públicas municipais no Rio Grande do Sul (Brasil). No estudo, a visão de uma ciência propositiva associa-se aos recursos tecnológicos que criam algoritmos e modelam aplicações com diversas funcionalidades. Desenvolveu-se um algoritmo associado a um software: o Elum. Relata-se, assim, a trajetória da pesquisa em que os dados acessados foram tratados (enquanto indicadores) e comunicados (enquanto comunicação pública) na busca por gerar uma equivalência cognitiva entre quem os dispõe e quem tem potencial interesse em compreendê-los.

PALAVRAS-CHAVE: Sistemas de informação; Política cultural; Administração pública

\section{RESUMEN:}

Este artículo presenta el resultado de investigación sobre la articulación entre indicadores, políticas culturales, comunicación pública y asignación de 


\section{Orevisto Observatório}

recursos realizada por las administraciones públicas municipales en Rio Grande do Sul (Brasil). En el estudio, la visión de una ciencia proposicional se asocia a recursos tecnológicos que crean algoritmos y modelan aplicaciones con diferentes funcionalidades. Se desarrolló un algoritmo asociado con el software: el Elum. Así, se reporta la trayectoria de investigación en la que los datos accedidos fueron tratados (como indicadores) y comunicados (como comunicación pública) en la búsqueda de generar una equivalencia cognitiva entre quién los tiene y quién tiene un potencial interés en comprenderlos.

PALABRAS-CLAVES: Sistemas de información; Política cultural; Administración pública.
e-ISSN no 2447-4266

Palmas, v. 7, n. 3, p. 1-17, jul.-set., 2021 http://dx.doi.org/10.20873/uft.2447-4266.2021v7n3a11en 